\title{
FAKTOR EKSTERNAL DAN FAKTOR INTERNAL TERHADAP MINAT BERWIRAUSAHA PADA SISWA SMK YAYASAN PENDIDIKAN ISLAM DARUSSALAM CERME GRESIK
}

\author{
Ine Ruswati \\ Fakultas Ekonomi dan Bisnis \\ Universitas Muhammadiyah Gresik \\ Jl. Sumatra 101 GKB Gresik
}

\begin{abstract}
ABSTRAK
Penelitian ini bertujuan melakukan pengujian Analisis Faktor Eksternal dan Faktor Internal Terhadap Minat Berwirausaha Pada Siswa SMK yayasan pendidikan Islam Darussalam Cerme Gresik. Kemudian dilakukan tinjauan pustaka dan penyusunan hipotesis, juga data yang diperolah dari penyebaran kuesioner terhadap 113 siswa SMK YPI DARUSSALAM Cerme menggunakan teknik Total sampling. Pengujian dilakukan dengan menggunakan analisis Regresi Linear Berganda. Hasil analisis memperlihatkan bahwa Motivasi Berpengaruh Terhadap Minat Berwirausaha SMK YPI Darussalam 1 Cerme, Harga Diri Berpengaruh Terhadap Minat Berwirausaha SMK YPI Darussalam 1 Cerme, Kreativitas Berpengaruh Secara Negatif Terhadap Minat Berwirausaha SMK YPI Darussalam 1 Cerme, Risk Taker Tidak Berpengaruh Terhadap Minat Berwirausaha SMK YPI Darussalam 1 Cerme, Lingkungan Keluarga Tidak Berpengaruh Terhadap Minat Berwirausaha SMK YPI Darussalam 1 Cerme dan Lingkungan Sekolah Berpengaruh Terhadap Minat Berwirausaha SMK YPI Darussalam 1 Cerme.
\end{abstract}

Keywords : Motvasi, Harga Diri, Kreativitas, Risk Taker

\section{PENDAHULUAN}

Kesulitan untuk mendapatkan pekerjaan menimbulkan banyak pengangguran di Indonesia (Mahanani, 2014). Pengangguran dan kemiskinan merupakan dua masalah yang masih menghantui masyarakat di banyak negara-negara berkembang termasuk di Indonesia hingga saat ini, dimana Indonesia termasuk negara nomor 4 yang memiliki jumlah total penduduk terbanyak di dunia. Pemerintah selalu berhadapan dengan permasalahan baru dalam bidang ekonomi dari tahun ke tahun, khususnya yang masih belum terselesaikan adalah angka pengangguran yang masih tinggi di Indonesia. Banyaknya jumlah penduduk Indonesia berdampak pada susahnya mendapatkan pekerjaan yang layak dan pada akhirnya banyak yang menyerah dan menjadi pengangguran. Hisrich et al, (2008) menyatakan bahwa kewirausahaan (entrepreneurship) adalah proses penciptaan sesuatu yang baru pada nilai menggunakan waktu dan upaya yang diperlukan, menanggung risiko keuangan, fisik, serta risiko sosial yang mengiringi, menerima imbalan moneter yang dihasilkan, serta kepuasan dan kebebasan pribadi.

Kewirausahaan penting bagi suatu negara sebagai pendukung kenaikan taraf perekonomian, para wirausaha dapat menciptakan industriindustri kreatif baru yang menstimulasi minat calon-calon wirausaha lainnya untuk bergabung bahkan mampu menyediakan lapangan pekerjaan baru bagi orang lain dan mampu menyerap tenaga kerja lebih banyak dengan tujuan mengurangi masalah pengangguran. Pengangguran di Indonesia terus meningkat seiring dengan berjalannya waktu dan yang lebih memprihatinkan adalah para sarjana yang tingkat pendidikannya bisa dikatakan tinggi juga banyak yang menjadi pengangguran. Badan Pusat Statistik (BPS) baru saja melansir jumlah penduduk yang tidak bekerja di Indonesia pada tahun 2014 adalah sebanyak 7.244.905 orang pengangguran terbuka, yang mana sebanyak 495.143 orang merupakan pengangguran intelektual atau lulusan Universitas Strata 1 
(Badan Pusat Statistik Indonesia, 2015). Hal ini sudah jelas menandakan bahwa sumbangsih fresh gradulate dalam bidang pengangguran cukup besar. Salah satu penyebab masalah pengangguran yang sudah lulus kuliah atau sarjana ini adalah banyaknya sarjana yang bertujuan hanya mencari pekerjaan, bukan menciptakan lapangan pekerjaan baru. Menjadi seorang wirausaha merupakan salah satu penentu maju atau mundurnya perekonomian, karena bidang wirausaha mempunyai kebebasan untuk berkarya dan mandiri (Oktarilis, 2012).

Lingkungan itu sendiri terbagi menjadi dua yaitu lingkungan internal dan lingkungan eksternal. Faktor lingkungan internal terdiri dari percaya diri, berorientasi pada tugas dan hasil, keberanian mengambil risiko, kepemimpinan, dan berorientasi pada masa depan. Sedangkan faktor lingkungan eksternal terdiri dari lingkungan ekonomi, lingkungan teknologi, lingkungan sosial dan keluarga, dan lingkungan demografi (Yuriski, 2008).

Gresik merupakan salah satu Kabupaten di Provinsi Jawa Timur dimana pola kehidupan masyarakat didominasi oleh kultur budaya Jawa. Kehidupan masyarakat Kabupaten Gresik sangat strategis dengan wilayah bisnis mandiri yang terintegrasi.Menurut statistik BPS, bahwa masyarakat Kabupaten Gresik didominasi oleh umur produktif sebanyak 76 ribu jiwa dari total jumlah penduduk sebesar 845 juta jiwa (BPS, 2015). Hal demikian sejalan dengan problematika lulusan tingkat SMK untuk membuka lapangan pekerjaan atau berwirausaha. Dimana, lulusan SMK diharapkan mampu menghasilkan lulusan yang siap kerja dan memiliki peluang besar untuk ikut mengembangkan ekonomi melalui kewirausahaan (BPS, 2015).

Pemerintah juga mengadakan Gerakan Kewirausahaan Nasional (GKN) 2013 yang terbuka untuk umum tetapi gerakan ini lebih diarahkan kepada kaum muda. GKN dimaksudkan untuk menciptakan karakterkarakter wirausaha yang tangguh dan handal, memiliki daya kreativitas dan inovasi yang tinggi sehingga mampu bersaing ditengah globalisasi perekonomian. Berdasarkan data Kementerian
Pendidikan dan Kebudayaan Nasional tahun 2016, minat lulusan lembaga pendidikan untuk berwirausaha sangat rendah, yaitu bagi lulusan SLTA / SMK (22,63persen) dan perguruan tinggi (6,14 persen). Sedangkan mereka yang berpendidikan SD dan SMP justru memiliki kemandirian untuk berusaha sendiri $(32,46$ persen). Terdapat kecenderungan para pemuda berpendidikan SLTA / SMK (61,877 persen) dan sarjana $(83,20$ persen $)$ memilih menjadi pekerja atau karyawan dibanding menjadi wirausaha. Hal ini berarti semakin tinggi tingkat pendidikan seseorang, semakin rendah kemandirian dan motivasi untuk menjadi wirausaha.

Penelitian ini akan dilakukan di SMK Yayasan Pendidikan Islam Darussalam Cerme Gresik yang memiliki sebuah Visi yaitu: Sekolah sebagai pusat keunggulan IMTAQ dan IPTEK berwawasan lingkungan serta mampu bersaing di era global selaras dengan kepribadian nasional. SMK Yayasan Pendidikan Islam Darussalam Cerme Gresik membimbing atau mengajarkan untuk berwirausaha dengan tujuan lulusan di SMK Yayasan Pendidikan Islam Darussalam Cerme Gresik dapat membuka lapangan pekerjaan sendiri dari pada mencari kerja setelah lulus sekolah. Menurut Wibisono (2006), visi merupakan rangkaian kalimat yang menyatakan cita-cita atau impian sebuah organisasi yang ingin dicapai di masa depan. Sedangkan misi merupakan rangkaian kalimat yang menyatakan tujuan atau alasan eksistensi organisasi yang memuat apa yang disediakan oleh organisasi kepada masyarakat serta untuk mencapai visinya.

Tujuan penelitian ini untuk mengetahui model motivasi, kepribadian, kreativitas, lingkungan sosial, keluarga ,dan lingkungan sekolah berpengaruh terhadap minat dalam berwirausaha.

\section{TINJAUAN PUSTAKA}

\section{Kewirausahaan}

Kewirausahaan adalah kemampuan kreatif dan inovatif yang dijadikan dasar, kiat dan sumber daya untuk mencari peluang menuju sukses. Inti dari kewirausahaan adalah kemampuan untuk menciptakan sesuatu yang baru dan berbeda 
melalui pemikiran kreatif dan tindakan inovatif demi terciptanya peluang. Banyak orang, baik pengusaha maupun yang bukan pengusaha, meraih sukses karena memiliki kemampuan kreatif dan inovatif (Suryana, 2010:2).

Suryana (2010:4) Terdapat beberapa bentuk pengetahuan tentang kewirausahaan yang harus dimiliki wirausaha, yaitu:

1. Pengetahuan mengenai usaha yang akan dirintis dan pengetahuan akan lingkungan usaha disekitarnya yang akan mempengaruhi kegiatan wirausaha.

2. Pengetahuan tentang peran dan tanggung jawab.

3. Pengetahuan tentang manajemen dan organisasi bisnis.

Kewirausahaan atau dulu juga disebut kewiraswastaan merupakan suatu profesi yang timbul, karena interaksi antara ilmu pengetahuan yang diperoleh dari pendidikan formal dengan seni yang hanya dapat diperoleh dari suatu rangkaian kerja yang diberikan dalam praktek. Oleh karena itu, seorang wirausaha, melakukan kegiatan mengorganisasikan berbagai faktor produksi sehingga menjadi suatu kegiatan ekonomi yang menghasilkan profit yang merupakan balas jasa atas kesediaannya mengambil resiko.

\section{Faktor Internal}

Suhartini (2011) faktor Intristik adalah faktorfaktor yang timbul karena pengaruh rangsangan dari dalam diri individu itu sendiri. Faktor Intristik menurut

Suhartini (2011) terdapat beberapa yaitu :

1. Pendapatan adalah penghasilan yang diperoleh seseorang baik berupa uang maupun barang. Berwiraswasta dapat memberikan pendapatan yang dapat digunakan untuk memenuhi kebutuhan hidupnya. Keinginan untuk memperoleh pendapatan itulah yang dapat menimbulkan minatnya untuk berwirausaha.

2. Harga Diri Berwiraswasta digunakan untuk meningkatkan harga diri seseorang, karena dengan usaha tersebut seseorang akan memperoleh popularitas, menjaga gengsi, dan menghindari ketergantungannya terhadap orang lain.

3. Perasaan Senang adalah suatu keadaan hati atau peristiwa kejiwaan seseorang, baik perasaan senang atau tidak senang. Perasaan erat hubungannya dengan pribadi seseorang, maka tanggapan perasaan senang berwiraswasta akan memunculkan minat berwiraswasta (Sirod Hantoro, 2005).

Stuart dan Sundeen dalam Haryanto (2010), mengatakan bahwa harga diri (self esteem) adalah penilaian individu terhadap hasil yang dicapai dengan menganalisa seberapa jauh perilaku memenuhi ideal dirinya. Atau dengan kata lain, harga diri merupakan menggambarkan sejauh mana individu tersebut menilai dirinya sebagai orang yang memiliki kemampuan, keberartian, berharga, dan kompeten. Sedangkan menurut Gilmore dalam Akhmad Sudrajad mengemukakan bahwa self esteem is a personal judgement of worthiness that is a personal that is expressed in attitude the individual holds toward himself artinya Self esteem adalah penilaian kelayakan pribadi yang diungkapkan dalam sikap seorang individu terhadap dirinya.

Pendapat ini menerangkan bahwa harga diri merupakan penilaian individu terhadap kehormatan dirinya, yang diekspresikan melalui sikap terhadap dirinya. Sementara itu, Buss (1973) memberikan pengertian mengenai harga diri (self esteem) sebagai penilaian individu terhadap dirinya sendiri, yang sifatnya implisit dan tidak diverbalisasikan. (Belajarpsikologi,2010) Menurut pendapat beberapa ahli tersebut, maka dapat disimpulkan bahwa harga diri (self esteem) adalah penilaian individu terhadap kehormatan diri, melalui sikap terhadap dirinya sendiri yang sifatnya implisit dan tidak diverbalisasikan dan menggambarkan sejauh mana individu tersebut menilai dirinya sebagai orang yang memeiliki kemampuan, keberartian, berharga, dan kompeten.

Faktor internal yang dipertimbangkan meliputi Locus of Control (LOC), N'ach, Risk Taking, Jiwa Entrepreneurship, emosi, kreatifitas, dan inovasi. Locus of Control(LOC) atau Letak Kendaliadalah merupakan variabel 
kepribadian yang berkaitan dengan harapan umum seseorang terhadap kemampuan untuk mengonrol peristiwa-peristiwa dalam kehidupan (Chairy, 2011). Berwirausaha merupakan suatu kegiatan yang memiliki resiko kerugian. Untuk menurunkan resiko kerugaian tersebut perlu melakukan perencanaan, dan evaluasi sebagai bagian dari adaptasi terhadap lingkungan bisnis. LOC berperan penting untuk menggerakkan aktifitas seseorang dalam merespon lingkungan bisnis. LOC terdiri dari 2 yaitu internal LOC dan Eksternal LOC. Orang dengan Internal LOC, mereka percaya bahwa dirinya yang dapat mempengaruhi llingkungan sedangkan ekternal LOC mereka percaya bahwa lingkungan yang mempengaruhi mereka.

\section{Faktor Eksternal}

Faktor lingkungan eksternal merupakan faktorfaktor dari luar individu yang mempengaruhi individu dan merupakan faktor yang tidak dapat dikendalikan (Mahanani 2014:38). Menurut Hayy dan Agus (2010) faktor eksternal adalah faktorfaktor yang mempengaruhi individu karena pengaruh rangsangan dari luar. faktor-faktor eksternal yang mempengaruhi minat berwirausaha antara lain: lingkungan keluarga, lingkungan pendidikan dan lingkungan masyarakat. Dewanti (2008:11) menyatakan bahwa kewirausahaan dipicu oleh faktor pribadi, lingkungan dan sosiologi. Faktor lingkungan yang berpengaruh menurut Dewanti adalah peluang yaitu situasi yang menguntungkan, model peranan, aktivitas, pesaing dengan industri yang sama, inkubator sebagai sumber ide, sumber daya alam dan manusia, teknologi dan kebijakan pemerintah.

Minat seseorang terhadap suatu obyek diawali dari perhatian seseorang terhadap obyek tersebut. Minat tidak dibawa sejak lahir, melainkan tumbuh dan berkembang sesuai dengan faktor-faktor yang mempengaruhinya. Minat dapat berubah-ubah tergantung dari faktorfaktor yang mempengaruhinya di antaranya adalah faktor lingkungan. Menurut Lupiyoadi (2007:12) faktor lingkungan yang mempengaruhi minat meliputi lingkungan keluarga, lingkungan pendidikan dan lingkungan masyarakat. Indarti dan Rostiani (2008:20) menyatakan ada tiga faktor lingkungan yang mempengaruhi wirausaha sukses yakni ketersediaan informasi, akses kepada modal dan kepemilikan jaringan sosial. Mazzarol dalam Saud (2009:2) menemukan bahwa faktor lingkungan (faktor sosial, ekonomi, politik dan perkembangan infrastruktur) mempengaruhi dorongan untuk mendirikan usaha. Zimmerer (2008:12) menyatakan bahwa faktor lingkungan seperti faktor ekonomi dan kependudukan, pergeseran dari ekonomi industri ke ekonomi jasa, kemajuan teknologi, perkembangan e-Commerce dan the world wide $w e b$, terbuka lebarnya peluang internasional dan perubahan gaya hidup masyarakat mempengaruhi minat kewirausahaan.

Keputusan pribadi untuk menjadi seorang pengusaha tidak hanya masalah faktor pribadi, tetapi juga isu-isu faktor lingkungan. Faktor lingkungan juga relevan karena lingkungan yang kondusif dapat langsung mempengaruhi keberhasilan bisnis baru (Bird dan Jarill dalam Ximenes 2014). Pembentukan organisasi baru memerlukan sumber daya termasuk sumber daya keuangan. Ketika seorang pengusaha mengubah ide mereka menjadi sebuah perusahaan, sumber daya keuangan merupakan faktor penting yang harus dipertimbangkan seperti lembaga keuangan, investor dan lain-lain. Ini penggunaan sumber daya keuangan untuk operasi pembiayaan seperti seperti uang jaminan, transaksi, dan lainlain, atau untuk investasi sebagai pinjaman (Evans dan Jovanovic dalam Ximenes 2014). Namun, Kim dalam ximenes (2014) menyatakan bahwa karena berbagai alasan, mendapatkan uang dari pinjaman bank atau investor dapat menjadi sulit karena mereka hanya memulai dan mungkin menghadapi risiko tinggi, pemberi pinjaman biasanya tidak mau memberikan modal dan beberapa kompensasi melalui biaya pinjaman. Berdasarkan teori pembangunan sosial, kebijakan dan program pemerintah memainkan peranan penting untuk memastikan perubahan kualitas dalam struktur dan kerangka masyarakat yang membantu masyarakat untuk mewujudkan tujuan dan tujuan hidup. Sebagai studi sebelumnya menunjukkan bahwa kebijakan 
pemerintah, lembaga, dan program dapat mempengaruhi bisnis dengan berbagai cara (Reynolds dalam Ximenes 2014:6). Ada juga muncul dalam masyarakat yang sering menghormati bagi mereka yang memiliki kerja keras dan keberhasilan memulai bisnis mereka sendiri. Melalui lingkungan di mana orang-orang sukses, pengusaha potensial dan pengusaha, di mana keduanya bisa mendiskusikan ide-ide, tantangan dan solusi, bisnis baru yang akan diproduksi (Gomezelj dalam Ximenes 2014:7).

Menurut Suhartini (2011) faktor entristik adalah faktor-faktor yang mempengaruhi individu karena pengaruh rangsangan dari luar. Faktor Entristik menurut Suhartini (2011) terdiri dari :

1. Lingkungan Keluarga adalah kelompok masyarakat terkecil yang terdiri dari ayah, ibu, anak, dan anggota keluarga yang lain. Keluarga merupakan peletak dasar bagi pertumbuhan dan perkembangan anak, disinilah yang memberikan pengaruh awal terhadap terbentuknya kepribadian. Rasa tanggung jawab dan kreativitas dapat ditumbuhkan sedini mungkin sejak anak mulai berinteraksi dengan orang dewasa. Orang tua adalah pihak yang bertanggung jawab penuh dalam proses ini. Salah satu unsur kepribadian adalah minat. Minat berwirausaha akan terbentuk apabila keluarga memberikan pengaruh positif terhadap minat tersebut, karena sikap dan aktifitas sesama anggota keluarga saling mempengaruhi baik secara langsung maupun tidak langsung. Orang tua yang berwirausaha dalam

2. bidang tertentu dapat menimbulkan minat anaknya untuk berwirausaha dalam yang sama pula.

3. Lingkungan Masyarakat merupakan lingkungan di luar lingkungan keluarga yaitu di kawasan tempat tinggalnya maupun dikawasan lain. Misalnya: seseorang yang tinggal didaerah yang terdapat usaha jasa elektronik atau sering bergaul dengan pengusaha elektronik yang berhasil akan menimbulkan minat berwirausaha bidang elektronik.
4. Peluang merupakan kesempatan yang dimiliki seseorang untuk melakukan apa yang dinginkannya atau menjadi harapannya. Misalnya: seseorang yang melihat suatu daerah yang jarang adanya usaha di bidang elektronik atau bahkan tidak ada usaha jasa dibidang tersebut, kemudian dia memanfaatkan peluang tersebut dengan membuka usaha bengkel service di tempat tersebut.

5. Pendidikan atau Pengetahuan yang di dapat selama kuliah merupakan modal dasar yang digunakan untuk berwiraswasta, juga keterampilan yang didapat selama diperkuliahan terutama dalam mata kuliah praktek.

\section{Minat Kewirausahaan}

Kasmir (2008:38) minat atau bakat ada dan dapat di timbulkan dalam diri seseorang.Artinya, ketertarikan pada suatu bidang sudah tertanam dalam dirinya. Minat juga dapat tumbuh setelah dipelajari dari berbagai cara. Namun, seseorang yang memiliki minat dari dalam atau bakat dari keturunan akan lebih mudah dan lebih cepat beradaptasi dalam mengembangkan usahanya. Riyanti (2003:21) menjelaskan bahwa minat adalah sumber motivasi yang mendorong seseorang untuk melakukan apa yang ingin dilakukan bila seseorang bebas memilih. Ketika seseorang menilai bahwa sesuatu akanbermanfaat, maka akan terbentuk minat yang kemudian hal tersebut akan mendatangkan kepuasan. Ketika

kepuasan menurun maka minatnya juga akan menurun sehingga minat tidak bersifat permanen, tetapi bersifat sementara atau dapat berubahubah.

Minat adalah sumber motivasi yang mendorong seseorang untuk melakukan apa yang ingin dilakukan bila seseorang bebas memilih. Ketika seseorang menilai bahwa sesuatu akan bermanfaat, maka akan terbentuk minat yang kemudian hal tersebut akan mendatangkan kepuasan. Ketika kepuasan menurun maka minatnya juga akan menurun sehingga minat tidak bersifat permanen, tetapi bersifat sementara atau dapat berubah-ubah (Mulyana, 2014:3). 
Minat berwirausaha adalah keinginan, ketertarikan serta kesediaan individu melalui ideide yang dimiliki untuk bekerja keras atau berkemauan keras untuk berusaha memenuhi kebutuhan hidupnya, percaya diri, kreatif, dan inovatif serta mempunyai kemampuan dan keterampilan untuk memenuhi kebutuhan (Fu'adi, 2009:93). Minat berwirausaha merupakan keinginan, ketertarikan, serta kesediaan individu untuk bekerja keras dalam memenuhi kebutuhan hidupnya tanpa takut dengan resiko yang akan terjadi (Yuliyaningsih, 2013:134).

Steinhoff dalam Suryana (2010:55) menyatakan bahwa ada tujuh alasan mengapa seseorang berminat terhadapkegiatan kewirausahaan, yakni:

1. Ingin memiliki penghasilan yang tinggi.

2. Ingin memiliki karier yang memuaskan.

3. Ingin bisa mengarahkan diri sendiri/tidak diatur oleh orang lain.

4. Ingin meningkatkan prestise diri sebagai pemilik bisnis.

5. Ingin menjalankan ide atau konsep yang dimiliki secara bebas.

6. Ingin memiliki kesejahteraan hidup dalam jangka panjang.

7. Ingin menyumbangkan sesuatu yang bermanfaat bagi kemanusiaan.

Seseorang yang memiliki bakat kewirausahaan dapat mengembangkan bakatnya melalui pendidikan.Mereka yang menjadi wirausaha adalah orang-orang yang mengenal potensi dan belajar mengembangkannya untuk menangkap peluang serta mengorganisasi usaha dalam mewujudkan cita-citanya (Suryana, 2013:2).

\section{Hipotesis}

Dalam penelitian ini diajukan sebuah hipotesis sebagai jawaban sementara terhadap permasalahan yang telah dikemukakan. Adapun hipotesis yang diajukan dalam penelitian ini adalah Ada pengaruh secara parsial dan simultan motivasi, harga diri, kreativitas, risk taker, lingkungan sekolah dan lingkungan sekolah terhadap minat berwirausaha siswa SMK YPI Darussalam 1 Cerme.

\section{METODE PENELITIAN}

Pendekatan penelitian yang digunakan dalam penelitian ini adalah pendekatan kuantitatif. Proses penelitian bersifat deduktif, di mana untuk menjawab rumusan masalah digunakan konsep atau teori. Penelitian kuantitatif menekankan pada fenomena-fenomena objektif dan dikaji secara kuantitatif. Maksimalisasi objektivitas desain penelitian kuantitatif menurut Sukmadinata (2009;530) dilakukan dengan menggunakan angka-angka, pengolahan statistik, struktur dan percobaan terkontrol. Metode penelitian yang tergolong ke dalam penelitian kuantitatif bersifat noneksperimental korelasional. Metode yang digunakan adalah metode asosiatif kausal. Merupakan hubungan yang sifatnya sebab akibat, salah satu variabel ( Independent ) mempengaruhi varibel yang lain ( Dependent).

\section{Populasi dan Sampel}

Populasi dalam suatu penelitian merupakan kumpulan individu atau obyek yang merupakan sifat-sifat umum. Arikunto (2010;173) menjelaskan bahwa "populasi adalah keseluruhan subjek penelitian." Maka dari penjelasan para ahli tersebut, penulis menetapkan populasi dalam penelitian ini adalah siswa kelas 3 di SMK YPI Darussalam 1 Cerme yang berjumlah 113 siswa.

Penarikan atau pembuatan sampel dari populasi untuk mewakili populasi disebabkan untuk mengangkat kesimpulan penelitian sebagai suatu yang berlaku bagi populasi. Arikunto (2010:174) mengatakan bahwa "sampel adalah sebagian atau wakil populasi yang diteliti. Metode penarikan sampel dalam penelitian ini adalah penelitian yang menggunakan seluruh anggota populasinya disebut sampel total (total sampling). Penggunaan metode ini berlaku jika anggota populasi relatif kecil (mudah dijangkau). Dalam penelitian ini, karena jumlah populasi relatif kecil dan relatif mudah dijangkau, maka penulis menggunakan metode total sampling. Dengan metode pengambilan sampel ini diharapkan hasilnya dapat cenderung lebih mendekati nilai sesungguhnya dan diharapkan dapat memperkecil pula terjadinya kesalahan / penyimpangan terhadap nilai populasi Usman \& 
Akbar, (2009;45) penelitian ini sampel yang diambil adalah 113 siswa kelas 3 SMK YPI Darussalam 1 Cerme.

\section{Identifikasi Variabel dan Definisi Operasional Variabel}

Sekaran $(2009 ; 115)$ menjelaskan bahwa variabel adalah apapun yang dapat membedakan atau membawa variasi pada nilai. Nilai bisa berbeda pada berbagai waktu untuk objek atau orang yang sama. Variabel penelitian yang digunakan dalam penelitian ini terdiri dari variabel bebas dan variabel terikat

1. Variabel bebas / Independent

Variabel Independent (bebas) adalah merupakan variabel yang mempengaruhi atau yang menjadi sebab perubahannya atau timbulnya variabel dependen (terikat). Variabel bebas yang digunakan dalam penelitian ini:
a. Motivasi (X1)
b. Kepribadian (X2)
c. Kreativitas (X3)
d. Risk Taker (X4)
e. Lingkungan Keluarga (X5)
f. Lingkungan Sekolah (X6)

2. Variabel terikat / Dependent

Variabel dependent (terikat) adalah suatu variabel yang dipengaruhi atau yang menjadi akibat, karena adanya variabel bebas. Penelitian ini yang menjadi variabel terikat adalah minat berwirausaha.

\section{Definisi Operasional Variabel}

Variabel-variabel yang digunakan dalam "Pengaruh Faktor Internal dan Eksternal Terhadap Minat Berwirausaha Siswa SMK YPI Darussalam 1 Cerme" adalah:

\section{Motivasi (X1)}

Menurut Uno (2008:1) mengemukakan "Motivasi adalah dorongan dasar yang menggerakkan seseorang bertingkah laku. Dorongan ini berada pada diri seseorang yang menggerakkan untuk melakukan sesuatu yang sesuai dengan dorongan dalam dirinya" Adapun indikator motivasi adalah:

a. Keinginan b. Adanya dorongan dalam berwirausaha.

c. Adanya cita-cita masa depan.

d. Adanya penghargaan dalam berwirausaha.

e. Adanya kegiatan yang menarik dalam berwirausaha.

2. Harga Diri (X2)

Harga diri merupakan penilaian individu terhadap hasil yang dicapai dengan menganalisa seberapa jauh perilaku memenuhi ideal dirinya. Adapun indikator yang digunakan adalah:
a. Lebih dihargai
b. Lebih percaya diri
c. Lebih nyaman berbicara dengan orang lain

3. Kreativitas (X3)

Kreativitas menunjukkan kemampuan individu untuk berimajinasi suatu hal yang berbeda dan menghasilkan ide karya yang merupakan hasil dari pikirian sendiri dan biasanya bersifat orisinil. Indikatornya kreativitas terdiri dari :
a. Memiliki inisiatif
b. Selalu mengutamakan imajinasi dalam berwirausaha
c. Memanfaatkan perbedaan
d. Orisinil

4. Risk Taker (X4)

Keberanian mengambil risiko menunjukkan presepsi kemauan dan sikap diri yang tidak takut akan bertindak danmenghadapi risiko yang tinggi serta selalu memperhitungkan akan risiko yang terjadi Suryana, 2003 dalam Mahanani (2014;61). Adapun indikator risk taker meliputi :
a. Menyukai tantangan
b. Kemampuan mencari peluang
c. Kemampuan menilai situasi risiko secara realistis
d. Penuh perhitungan

5. Lingkungan Keluarga (X5)

Lingkungan keluarga dalam penelitian ini adalah sejauh mana peran dari lingkungan keluarga mempengaruhi keberlangsungan aktivitas wirausaha yang dijalankan Yusuf 
(2009:42). Adapun indikator lingkungan keluarga meliputi:

a. Fungsi keluarga,

b. Sikap dan perlakuan orang tua terhadap anak,

c. Status ekonomi.

6. Lingkungan Sekolah (X6)

Lingkungan sekolah menggambarkan

lingkungan di luar individu disekitar sekolah individu itu mencakup segala kegiatan individu di sekolah.. Adapun indikator lingkungan sekolah meliputi:

a. Motivasi dari guru

b. Pembelajaran kewirausahaan

c. Ekstrakurikuler entrepreneur

7. Minat Berwirausaha (Y)

Minat berwirausaha menunjukkan presepsi akan rasa ketertarikan dan keinginan dari dalam individu seseorang untuk menciptakan suatu bisnis baru Fatrika et al (2009) . Adapun indikator kinerja meliputi:

a. Perasaan tertarik untuk berwirausaha

b. Perasaan senang untuk berwirausaha

c. Berniat untuk direalisakan dimasa yang akan datang

\section{Jenis dan Sumber Data}

Pada penelitian ini, jenis dan sumber data yang dipakai oleh peneliti adalah sebagai berikut:

1. Data Primer

Data primer merupakan informasi yang dikumpulkan langsung dari sumbernya Narimawati (2008;98).Dalam penelitian ini, data primer diperoleh melalui daftar pertanyaan kuesioner yang diberikan kepada responden, yaitu siswa kelas 3 SMK YPI Darussalam 1 Cerme, yang berada di Jl. Pasar Cerme Lor No. 03 Kecamatan Cerme Kabupaten Gresik.

2. Data Sekunder

Data yang diperoleh secara tidak langsung, baik berupa keterangan maupun literature yang ada hubungannya dengan penelitian yang sifatnya melengkapi atau mendukung data primer menurut Narimawati $(2008 ; 98)$. Data sekunder yang digunakan dalam penelitian ini adalah dan berupa bukti catatan atau laporan yang telah tersusun dalam arsip yang dipublikasikan berupa sejarah, struktur organisasi guru data jumlah siswa kelas 3 SMK YPI Darussalam 1 Cerme, yang berada di Jl. Pasar Cerme Lor No. 03 Kecamatan Cerme Kabupaten Gresik.

\section{Teknik Pengambilan Data}

Teknik pengambilan data penelitian ini dengan metode angket (kuesioner). Kuesioner yaitu memperoleh data dengan cara mengajukan daftar pertanyaan tertulis secara lengkap tentang masalah yang akan dibahas, tentang faktor intetrnal dan eksternal terhadap minat berwirausaha siswa pada siswa kelas 3 SMK YPI Darussalam 1 Cerme, yang berada di Jl. Pasar Cerme Lor No. 03 Kecamatan Cerme Kabupaten Gresik.

\section{Teknik Analisis Data}

Analisis ini digunakan untuk mengetahui apakah variabel Motivasi, harga diri, Kreativitas,Risk Taker,Lingkungan Keluarga, Lingkungan Sekolah terhadap minat wirausaha SMK YPI Darussalam Cerme Gresik.

\section{HASIL DAN PEMBAHASAN}

Pengujian dilakukan dengan bantuan SPSS didapatkan hasil berdasarkan tujuan penelitian untuk mengetahui pengaruh variabel bebas (X) terhadap variabel terikat (Y)Analisis ini bertujuan untuk mengetahui pengaruh variabel bebas (X) terhadap variabel terikat (Y).

$$
\mathrm{Y}=\mathrm{a}+\mathrm{b}_{1} \mathrm{X}_{1}+\mathrm{b}_{2} \mathrm{X}_{2}+\mathrm{b}_{3} \mathrm{X}_{3}+\mathrm{b}_{4} \mathrm{X}_{4}+\mathrm{b}_{5} \mathrm{X}_{5}+
$$

$$
\mathrm{b}_{6} \mathrm{X}_{6}+\mathrm{e}
$$

\section{Keterangan :}

$\mathrm{Y} \quad=$ Minat

$\mathrm{a} \quad=$ Konstanta

$\mathrm{X}_{1} \quad=$ Motivasi

$\mathrm{X}_{2} \quad=$ Harga Diri

$\mathrm{X}_{3} \quad=$ Kreativitas

$\mathrm{X}_{4} \quad=$ Risk Taker

$\mathrm{X}_{5} \quad$ = Lingkungan Keluarga

$\mathrm{X}_{6} \quad=$ Lingkungan Sekolah

$\mathrm{b}_{1}-\mathrm{b} 4_{1}=$ koifisien regresi

$\mathrm{e} \quad=$ standart error 
Berdasarkan pengolahan data diperoleh hasil yang diringkas sebagai berikut : $\mathrm{Y}=-0,830+0,307 \mathrm{X}_{1}+0,421 \mathrm{X}_{2}-0,326 \mathrm{X}_{3}+$ $0,032 \mathrm{X}_{4}+0,025 \mathrm{X}_{5}+0,466 \mathrm{X}_{6}+\mathrm{e}$

1. Nilai $a=-0,830$ menunjukkan bahwa, jika variabel motivasi (X1), harga diri (X2), kreativitas (X3), risk taker (X4), lingkungan keluarga (X5), lingkungan sekolah (X6), bernilai 0 , maka variabel minat berwirausaha $(\mathrm{Y})$ berkurang $-0,830$ satuan .

2. Jika motivasi (X1) berubah dengan satuan nilai, maka $\mathrm{Y}$ akan naik sebesar 0,307 satuan, dengan harga diri (X2), kreativitas (X3), risk taker (X4), lingkungan keluarga (X5), lingkungan sekolah (X6) tetap. Dari pernyataan berikut dapat di jelaskan bahwa jika Motivasi semakin tinggi dengan asumsi variabel lain tetap maka minat wirausaha akan mengalami peningkatan.

3. Jika harga diri (X2) berubah dengan satuan nilai, maka Y akan naik sebesar 0,421 satuan, dengan asumsi variabel motivasi (X1), kreativitas (X3), risk taker (X4), lingkungan keluarga (X5), lingkungan sekolah (X6), tetap. Dari pernyataan berikut dapat di jelaskan bahwa jika Harga diri semakin tinggi dengan asumsi variabel lain tetap maka minat wirausaha akan mengalami peningkatan

4. Jika kreativitas (X3) berubah dengan satu satuan nilai, maka $\mathrm{Y}$ akan turun sebesar 0,326 satuan. dengan asumsi variabel motivasi (X1), harga diri (X2), risk taker (X4), lingkungan keluarga (X5), lingkungan sekolah (X6), tetap. Dari pernyataan berikut dapat di jelaskan bahwa jika Kreativitas semakin menurun dengan asumsi variabel lain tetap maka minat wirausaha akan mengalami peningkatan.

5. Jika risk taker (X4) berubah dengan satu satuan nilai, maka Y akan naik sebesar 0,032 satuan. dengan asumsi variabel motivasi (X1), harga diri (X2), kreativitas (X3), lingkungan keluarga (X5), lingkungan sekolah (X6), tetap. Dari pernyataan berikut dapat di jelaskan bahwa jika Risk Taker semakin meningkat dengan asumsi variabel lain tetap maka minat wirausaha akan mengalami peningkatan

6. Jika Lingkungan keluarga (X5) berubah dengan satu satuan nilai, maka $\mathrm{Y}$ akan naik sebesar 0,025 satuan. dengan asumsi variabel motivasi (X1), harga diri (X2), kreativitas (X3), risk taker (X4), lingkungan sekolah (X6), tetap. Dari pernyataan berikut dapat di jelaskan bahwa jika Lingkungan keluarga semakin meningkat dengan asumsi variabel lain tetap maka minat wirausaha akan mengalami peningkatan

7. Jika lingkungan sekolah (X6) berubah dengan satu satuan nilai, maka $\mathrm{Y}$ akan naik sebesar 0,313 satuan. dengan asumsi variabel motivasi (X1), harga diri (X2), kreativitas (X3), risk taker (X4), lingkungan keluarga (X5), tetap. Dari pernyataan berikut dapat di jelaskan bahwa jika Lingkungan sekolah semakin meningkat dengan asumsi variabel lain tetap maka minat wirausaha akan mengalami peningkatan.

Hasil koefisien Determinasi ( $\mathrm{R}^{2}$ ) dan koefisien korelasi ganda, diperoleh hasil sebagai berikut:

1. Dari hasil Adjusted R Square $=0,752$ dapat dikatakan bahwa perubahan variabel terikat keputusan mahasiswa (Y) sebesar 75,2\% mampu menjelaskan terhadap variabel variabel motivasi (X1), harga diri (X2), kreativitas (X3), risk taker (X4), lingkungan keluarga (X5), lingkungan sekolah (X6), sedangkan sisanya $24,8 \%$ disebabkan oleh faktor lain yang tidak ada dalam model ini

2. $\mathrm{R}$ square sebesar 0,766 artinya proporsi variasi dalam variabel bebas terhadap variabel variabel variabel motivasi (X1), harga diri (X2), kreativitas (X3), risk taker (X4), lingkungan keluarga (X5), lingkungan sekolah (X6), mampu menjelaskan variabel terikat minat berwirausaha (Y) sebesar $76,6 \%$ sedangkan selebihnya $23,4 \%$ disebabkan oleh faktor lain yang tidak ada dalam model ini. 
3. $\mathrm{R}=0,875$ artinya kuatnya hubungan antar variabel independen (X) bersama-sama terhadap variabel (Y) yaitu $86,5 \%$.

Hasil uji hipotesis adalah sebagai berikut:

Uji hipotesis dilakukan untuk mengetahui apakah variabel eksogen berpengaruh terhadap variabel endogen yang digunakan dalam penelitian. Uji hipotesis yang digunakan adalah uji t. Uji t digunakan untuk melihat pengaruh parsial (masing-masing) variabel eksogen terhadap variabel endogen. Tingkat kepercayaan atau tingkat signifikansi yaitu $\propto=5 \% \div 2=2,5 \%$. Perumusan hipotesisnya adalah sebagai berikut:

Jika $t_{\text {hitung }}>t_{\text {tabel, }}$ maka Ho ditolak dan Ha diterima

Jika $t_{\text {hitung }}<\mathrm{t}_{\text {tabel }}$, maka Ho diterima dan Ha ditolak

1. Pengaruh variabel Motivasi (X1) terhadap Minat Berwirausaha (Y)

Pengolahan data dengan menggunakan SPSS, diperoleh nilai t hitung sebesar 4,481 dan nilai $\mathrm{t}$ tabel dengan taraf signifikansi 0,025 (dua sisi) sebesar 1,982. Selanjutnya nilai $t$ hitung dan $t$ tabel dibandingkan,Berdasarkan hasil perhitungan, nilai $t_{\text {hitung }}$ sebesar 4,481 > nilai $t_{\text {tabel }}$ sebesar 1,982, maka Ho ditolak dan Ha diterima. Dapat disimpulkan, bahwa motivasi berpengaruh secara parsial terhadap minat berwirausaha.

2. Pengaruh variabel Harga Diri $\left(X_{2}\right)$ terhadap Minat Berwirausaha (Y)

Pengolahan data dengan menggunakan SPSS, diperoleh nilai t hitung sebesar 5,022 dan nilai $\mathrm{t}$ tabel dengan taraf signifikansi 0,025 (dua sisi) sebesar 1,982. Berdasarkan hasil perhitungan, nilai $t_{\text {hitung }}$ sebesar 5,022 > nilai $t_{\text {tabel }}$ sebesar 1,982, maka Ho ditolak dan Ha diterima. Dapat disimpulkan, bahwa harga diri berpengaruh secara parsial terhadap minat berwirausaha SMK YPI Darussalam 1 Cerme.

3. Pengaruh variabel Kreativitas $\left(\mathrm{X}_{3}\right)$ terhadap Minat Berwirausaha (Y)
Pengolahan data dengan menggunakan SPSS, diperoleh nilai t hitung sebesar $-3,436$ dan nilai $\mathrm{t}$ tabel dengan taraf signifikansi 0,025 (dua sisi) sebesar 1,982. Berdasarkan hasil perhitungan, nilai $t_{\text {hitung }}$ sebesar $3,436>$ nilai $t_{\text {tabel }}$ sebesar 1,982, maka Ho ditolak dan Ha diterima. Dapat disimpulkan, bahwa kreativitas berpengaruh secara negatif terhadap minat berwirausaha SMK YPI Darussalam 1 Cerme.

4. Pengaruh variabel Risk Taker (X4) terhadap Minat Berwirausaha (Y)

Pengolahan data dengan menggunakan SPSS, diperoleh nilai t hitung sebesar 0,425 dan nilai $\mathrm{t}$ tabel dengan taraf signifikansi 0,025 (dua sisi) sebesar 1,982. Berdasarkan hasil perhitungan, nilai $t_{\text {hitung }}$ sebesar $0,425<$ nilai $t_{\text {tabel }}$ sebesar 1,982 , maka Ho diterima dan Ha ditolak. Dapat disimpulkan, bahwa risk taker tidak berpengaruh terhadap minat berwirausaha SMK YPI Darussalam 1 Cerme.

5. Pengaruh variabel Lingkungan Keluarga (X5) terhadap Minat Berwirausaha (Y)

Pengolahan data dengan menggunakan SPSS, diperoleh nilai t hitung sebesar 0,230 dan nilai $\mathrm{t}$ tabel dengan taraf signifikansi 0,025 (dua sisi) sebesar 1,982. Berdasarkan hasil perhitungan, nilai $t_{\text {hitung }}$ sebesar $0,230<$ nilai $t_{\text {tabel }}$ sebesar 1,982 , maka Ho diterima dan Ha ditolak. Dapat disimpulkan, bahwa lingkungan keluarga tidak berpengaruh secara parsial terhadap minat berwirausaha SMK YPI Darussalam 1 Cerme.

6. Pengaruh variabel Lingkungan Sekolah (X6) terhadap Minat Berwirausaha (Y)

Pengolahan data dengan menggunakan SPSS, diperoleh nilai t hitung sebesar 4,145 dan nilai $\mathrm{t}$ tabel dengan taraf signifikansi 0,025 (dua sisi) sebesar 1,982. Berdasarkan hasil perhitungan, nilai $\mathrm{t}_{\text {hitung }}$ sebesar 4,145> nilai $t_{\text {tabel }}$ sebesar 1,982, maka Ho ditolak dan Ha diterima. Dapat disimpulkan, bahwa lingkungan sekolah berpengaruh secara parsial terhadap minat berwirausaha SMK YPI Darussalam 1 Cerme. 
7. Pengaruh secara simultan motivasi, harga diri, kreativitas, risk taker, lingkungan sekolah dan lingkungan sekolah terhadap minat berwirausaha siswa SMK YPI Darussalam 1 Cerme. Berdasarkan hasil uji F, bahwa F hitung 57,718 > F tabel 2,18 dan nilai signifikan $\mathrm{F}$ yang lebih kecil dari 0,05 $(0,000<0,05)$. Dengan demikian dapat dikatakan bahwa motivasi (X1), harga diri (X2), kreativitas (X3), risk taker (X4), lingkungan keluarga (X5), lingkungan sekolah (X6) secara simultan minat berwirausaha SMK YPI Darussalam 1 Cerme (Y).

\section{Pembahasan}

Hasil penelitian menunjukkan bahwa nilai $t$ hitung/t penelitian sebesar 4,481 > nilai t tabel sebesar 1,982, sehingga Ho ditolak dan $\mathrm{Ha}$ diterima. Dapat disimpulkan bahwa terdapat pengaruh antara motivasi terhadap minat berwirausaha. Motivasi adalah istilah untuk menjelaskan apa yang mendorong dan apa yang menggerakkan kegiatan manusia, artinya apa saja yang dapat mendorong mengerakkan seseorang untuk melakukan sesuatu. Motivasi berwirausaha setiap orang, satu dengan yang lainnya, bisa jadi tidak sama. Biasanya, hal itu bergantung dari apa yang diinginkan orang yang bersangkutan. Motivasi dianggap sebagai faktor penting dalam minat berwirausaha karena motivasi dapat menyebabkan, menyalurkan dan mendukung perilaku manusia, supaya mau bekerja giat dan antusias mencapai hasil yang optimal (Yuliyaningsih, 2013:200).

Hasil penelitian menunjukkan bahwa nilai $\mathrm{t}$ hitung/t penelitian sebesar 5,022> nilai $\mathrm{t}$ tabel sebesar 1,982, sehingga Ho ditolak dan $\mathrm{Ha}$ diterima. Dapat disimpulkan bahwa terdapat pengaruh antara harga diri terhadap minat berwirausaha Smk YPI Darussalam 1 Cerme. Menurut Robinson (1991), beberapa karakteristik Psikologis internal sebagai penentu dari minat berwirausaha yaitu: Harga diri adalah bagaimana individu menilai dirinya sendiri berdasarkan evaluasi yang positif ataupun negatif tentang kemampun, kebehargaan, penting dan dapat diterima oleh orang lain. Harga diri dapat menumbuhkan minat berwirausaha pada individu, dimana individu yang memiliki harga diri yang tinggi, menilai dirinya berharga, akan mampu melakukan sesuatu dalam berwirausaha, sehingga minat individu juga akan tinggi terhadap wirausaha begitu sebaliknya.

Hasil penelitian menunjukkan bahwa nilai t hitung/t penelitian sebesar $-3,436>$ nilai t tabel sebesar -1,982, sehingga Ho ditolak dan $\mathrm{Ha}$ diterima. Dapat disimpulkan bahwa terdapat pengaruh negatif antara kreativitas terhadap minat berwirausaha Smk YPI Darussalam 1 Cerme. Pengembangan potensi dan kreativitas anak juga dapat memberikan pengaruh bagi minat kewirausahaan siswa.Siswa yang kreatif cenderung mampu menghasilkan produk-produk atau ide-ide usaha yang dapat diproduksi dan dipasarkan (Munandar, 2012). Kegiatan seperti ini nantinya akan dapat menumbuhkan minat kewirausahaan pada siswa. Oleh karena itu, diduga kreativitas siswa berhubungan dengan minat kewirausahaan pada siswa.Semakin baik kreativitas siswa, maka semakin baik pula minat kewirausahaan pada siswa

Hasil penelitian menunjukkan bahwa nilai $\mathrm{t}$ hitung/t penelitian sebesar $0,425<$ nilai $\mathrm{t}$ tabel sebesar 1,982, sehingga Ho diterima dan $\mathrm{Ha}$ ditolak. Dapat disimpulkan bahwa tidak terdapat pengaruh antara risk taker terhadap minat berwirausaha Smk YPI Darussalam 1 Cerme. Risk taker tidak mempengaruhi minat berwirausaha siswa SMK YPI Darussalam 1 Cerme gresik dikarenakan tidak adanya pelatihan kewirausahaan sehingga semua siswa berani dalam mengambil resiko mereka lebih memilih zona nyaman menjadi pekerja dari pada menjadi wirausaha. Kurangnya pengetahuan untuk mengambil resiko juga sebagai penentu tidak berpengaruhnya risk taker terhadap minat berwirausaha.

Hasil penelitian menunjukkan bahwa nilai t hitung/t penelitian sebesar $0,230<$ nilai $t$ tabel sebesar 1,982, sehingga Ho diterima dan $\mathrm{Ha}$ ditolak. Dapat disimpulkan bahwa tidak ada pengaruh antara lingkungan sekolah terhadap terhadap minat berwirausaha Smk YPI 
Darussalam 1 Cerme. Lingkungan keluarga tidak mempengaruhi minat berwirausaha siswa SMK YPI Darussalam 1 Cerme gresik dikarenakan tidak semua didalam kelurga mendukung untuk minat berwirausaha dan kurangnya akan pengetahuan tentang berwirausaha. Kebanyakan siswa dituntut untuk mecari kerja dari pada memulai wirausaha yang membutuhkan modal dan perencanaan yang matang untuk minat berwirausaha. Keputusan pribadi untuk menjadi seorang pengusaha tidak hanya masalah faktor pribadi, tetapi juga isu-isu faktor lingkungan. Faktor lingkungan juga relevan karena lingkungan keluarga yang tidak mendukung.

Hasil penelitian menunjukkan bahwa nilai t hitung/t penelitian sebesar $4,145>$ nilai $t$ tabel sebesar 1,982, sehingga Ho ditolak dan $\mathrm{Ha}$ diterima. Dapat disimpulkan bahwa terdapat pengaruh antara lingkungan sekolah terhadap minat berwirausaha Smk YPI Darussalam 1 Cerme. Menurut Ibnu (2003) dalam Mahanani (2014;47), pendidikan entrepreneur akan menjadi jalur baru bagi siswa untuk mempunyai potensi dalam berkreasi dan berinovasi. Siswa akan mempunyai jiwa eksplorasi untuk mencari peluang dan berani mengambil resiko untuk mencoba hal-hal baru. Linan dalam Began et.al. (2013) dalam Mahanani (2014;47) menyatakan pendidikan kewirausahaan mencoba untuk mengembangkan niat siswa untuk melakukan perilaku kewirausahaan, pengetahuan dan keinginan kewirausahaan dari aktivitas kewirausahaan.

Wang dan Wong (2004) dalam Mahanani (2014;48) yang menunjukkan bahwa impian kewirausahaan dari banyak siswa terhalang oleh kurangnya persiapan lembaga akademis. Sistem sekolah dan pendidikan juga memainkan peran penting dalam mengidentifikasi dan membentuk ciri-ciri kewirausahaan (Ibrahim \& Soufani, 2002) dalam Mahanani (2014;48). Dengan demikian keadaan lingkungan sekolah dapat membentuk karakter, potensi, serta minat siswa dengan adanya pengajaran, kurikulum, serta kegiatan ekstrakurikuler.

Hasil uji hipotesis secara simultan melalui uji $\mathrm{F}$ menyatakan bahwa variabel motivasi, harga diri, kreativitas, risk taker, lingkungan keluarga dan lingkungan sekolah secara simultan terhadap minat berwirausaha smk ypi darussalam 1 cerme. Kesimpulan ini didasarkan pada hasil analisis yang menunjukkan nilai $\mathrm{F}$ hitung 57, $718>\mathrm{F}$ tabel 2,18 pada taraf signifikan $5 \%$. variabel produk jasa, price, place, promosi people, phiscal evidence dan process.

Seorang wirausahawan adalah seorang yang memiliki keahlian untuk menjual, mulai dari menawarkan ide hingga komoditas baik berupa produk atau jasa. Seorang wirausahawan (entrepreneur) adalah seseorang yang menciptakan bisnis baru dengan mengambil risiko dan ketidakpastian demi mencapai keuntungan dan pertumbuhan dengan cara mengidentifikasi peluang yang signifikan dan menggabungkan sumber-sumber daya yang diperlukan sehingga sumber-sumber daya itu bisa dikapitalisasikan (Zimmerer, 2008). Dengan kreativitasnya, wirausahawan mampu beradaptasi dengan berbagai situasi dan kondisi lingkungan. Sebagai pelaku bisnis, wirausahawan harus mengetahui dengan baik manajemen penjualan, gaya dan fungsi manajemen. Untuk berhasil, harus mampu berkomunikasi dan menguasai beberapa elemen kecakapan manajerial, serta mengetahui teknik menjual yang strategis mulai dari pengetahuan tentang produk, ciri khas produk dan daya saing produk terhadap produk sejenis (Mahesa, 2012). Wirausahawan berani mengambil risiko yang terkait dengan proses pemulaian. Menurut Randy (2013), Entrepreneur yang kuat dan dengan jumlah yang banyak membuat bangsa ini semakin kokoh dalam menjaga stabilitas ekonomi bangsa. Ekonomi yang stabil membuat bangsa ini kuat terhadap badai krisis keuangan ataupun krisis global yang terjadi saat ini. Di samping menjaga stabilitas ekonomi bangsa dengan banyaknya entrepreneur banyak memberikan lapangan pekerjaan bagi masyarakat luas. Untuk itu perlu adanya sosialisasi lebih mengenani entrepreneurship kepada masyarakat luas yang tentunya sangat memberikan manfaat tersendiri. 


\section{SIMPULAN}

Berdasarkan hasil penelitian di atas yang merupakan implikasi dari hasil penelitian yang dilakukan mengenai pengaruh terhadap minat berwirausaha pada SMK YPI Darussalam Gresik, maka dapat disampaikan saran sebagai berikut:

1. Adanya pengaruh nyata antara motivasi, harga diri, kreativitas, Risk Taker, Lingkungan Keluarga, Lingkungan Sekolah terhadap minat berwirausaha di SMK YPI Darussalam Gresik, maka dari pihak SMK YPI Darussalam Gresik harus mempertahankan variabel-variabel tersebut agar minat berwirausaha pada SMK YPI Darussalam Gresik dapat berkembang. Dengan hasil penelitian ini, dapat memberikan pemahaman bahwa dengan pendapatan usaha yang tinggi, maka akan menjadikan motivasi bagi para responden untuk menjadi pewirausaha, dan menjadikan mandiri dengan memperoleh penghasilan yang lebih potensial dibanding bekerja dengan pihak lain. Dan dengan banyaknya pengetahuan kewirausahaan yang dimiliki, dan juga dorongan motivasi informal dari dalam lingkungan keluarga, maka akan meningkatkan minat responden untuk berwirausaha.

2. Kreativitas terhadap minat berwirausaha di SMK YPI Darussalam Gresik, mempunyai nilai pengaruh kecil dibanding variabel lainnya, sehingga kreativitas yang mempunyai nilai lebih kecil.

3. Risk taker dan Lingkungan Keluarga terhadap minat berwirausaha di SMK YPI Darussalam Gresik, mempunyai nilai pengaruh lebih kecil dibanding variabel lainnya, sehingga yang mempunyai nilai lebih kecil tersebut agar lebih ditingkatkan, dengan selalu meningkatkan pengetahuan responden tentang resiko berwirausaha baik dengan cara banyak mengikuti kursus kewirausahaan, dengan cara melihat persaingan dalam berwirausaha dan selalu memberikan pendidikan informal dari lingkungan keluarga untuk menjadi wirausaha sehingga minat berwirausaha tetap terjaga. Karena dengan demikian akan membentuk keterampilan dasar dan menjadi bekal di masa mendatang. Dengan hasil penelitian ini, dapat memberikan pemahaman kepada para responden bahwa dengan banyaknya pengetahuan tentang resiko berwirausaha yang dimiliki, maka dapat menangkap peluang usaha dan berani mengambil resiko yang akan meningkatkan minat untuk berwirausaha.

4. Motivasi, Harga diri dan Lingkungan sekolah terhadap minat berwirausaha di SMK YPI Darussalam Gresik mempunyai nilai pengaruh lebih besar dibanding variabel lainnya, maka sebaiknya agar dipertahankan. Dengan adanya variabel diatas rata-rata, maka akan menjadikan motivasi bagi para responden untuk berwirausaha, dan menjadikan mandiri dengan memperoleh penghasilan sendiri yang lebih potensial dibanding bekerja dengan pihak lain, sehingga minat berwirausaha tetap terjaga. Dengan hasil penelitian ini dapat memberikan pemahaman kepada para responden bahwa dengan berwirausaha akan mendapatkan hasil yang lenih tinggi dibanding dengan bekerja dengan perusahaan-perusahaan besar lainnya.

\section{DAFTAR PUSTAKA}

Achmad Syaifudin. 2016 "Pengaruh Kepribadian, Lingkungan Keluarga Dan Pendidikan Kewirausahaan Terhadap Minat Berwirausaha Mahasiswa Program Studi Akuntansi Universitas Negeri Yogyakarta" Program Studi Akuntansi Jurusan Pendidikan Akuntansi Fakultas Ekonomi Universitas Negeri Yogyakarta.

Algifari. 2009. Analisis Statistik untuk Bisnis dengan Regresi, Korelasi, dan Nonparametrik. Edisi Pertama. Yogyakarta: BPFE.

Alma Buchari. 2008. Pengantar Bisnis, Bandung : Alfabeta

Anoraga, Pandji. 2009. Manajemen Bisnis. Jakarta : PT. Rineka Cipta. 
Arikunto, S. 2010. Prosedur Penelitian Suatu pendekatan praktik. Jakarta: PT Rineka Cipta

Buchari Alma. 2011. Manajemen Pemasaran dan Pemasaran Jasa. Bandung : Penerbit Alfabeta.

Chairy. 2011. Pengaruh Karakteristik Entrepreneurial, Jenis Etnis, Jenis Kelamin dan Profesi Orang Tua Terhadap Intensi Berwirausaha Mahasiswa. Prosiding Dalam Rangkaian Seminar Internasional Dan Call For Papers "Towards Excellent Small Business".

Dewanti, Retno.2008.Kewirausahaan. Jakarta: Mitra Wacana Media.

Fuadi, Ahmad. 2009. Negeri Lima Menara. Jakarta: Gramedia Pustaka Utama.

Gujarati, Damodar. 2006. Dasar-Dasar Ekonometrika.Jakarta: Erlangga.

Ghozali, Imam, 2009. Aplikasi Analisis Multivariate Dengan Program SPSS, Edisi Keempat, Penerbit Universitas Diponegoro.

Gurol, Y. and Atsan, N. (2006). "Entrepreneurial characteristics amongs university

students. Some insights for entrepreneurship education and training in Turkey,"Education and Training.

Hantoro Sirod. (2005). Kiat Sukses Berwirausaha. Yogyakarta: Adi Karya Nusa.

Handoko, Hani T. (2003). Manajemen. Yogyakarta. Penerbit: BPFE.

Hendro, 2011. Dasar - Dasar Kewirausahaan, Erlangga, Jakarta.

Hendro dan Chandra W. Widhianto. 2006. Be a Smart and Good Entrepreneur. CLA, Bekasi Hisrich, R. D., et al. 2008. Entrepreneurship. Edisi 7. Jakarta: Salemba Empat.

Indarti dan Rostiani,R. 2008. Intensi Kewirausahaan Mahasiswa: Studi Perbandingan Antara Indonesia, Jepang dan Norwegia. Jurnal Ekonomika dan Bisnis Indonesia, Vol. 23, No. 4, Oktober 2008

Kasmir, 2007. Kewirausahaan, Edisi 1, Penerbit PT RajaGrafindo Persada, Jakarta.

Kristsada Agatha Dita. 2010. Peningkatan Minat Membaca Pelajaran Bahasa Indonesia melalui Layanan Bimbingan Belajar dengan Teknik Diskusi Kelompok pada Siswa Kelas XI AP/AK SMK MARSUDI LUHUR 1 Yogyakarta. Skripsi. FIP UNY
Larsen, P. \& A. Lewis. 2007. "How Award Winning SMEs Manage The Barriers to Innovation", Journal Creativity and Innovation Management, page: 141-151.

Lupiyoadi, Rambat, 2007, Manajemen Pemasaran Jasa, Salemba Empat, Jakarta

Machfoedz, Mahmud. 2005. Kewirausahaan : Metode, Manajemen, dan Implementasi. Yogyakarta : BPFE - Yogyakarta

Maharani, Ervina. 2014. Panduan Sukses Menulis Penelitian Tindakan Kels. Yogyakarta: Parasmu.

Mahesa Aditya Dion. 2012. Analisis FaktorFaktor Motivasi Yang Mempengaruhi Minat Berwirausaha (studi pada Mahasiswa S1 Fakultas Ekonomika dan Bisnis Universitas Diponegoro). Skripsi UNDIP.

Mulyana, Deddy. Ilmu Komunikasi: Suatu Pengantar. Cetakan ke 18. Bandung: PT. Remaja Rosdakarya, 2014.

Munandar, S.C. Utami. 2012. Pengembangan Kreativitas Anak Berbakat. Rineka Cipta. Jakarta.

Nickels, William G. 2005. Understanding Business, McGraw-Hill, New York.

Oktarilis Nur Shabrina. 2012. Pengaruh FaktorFaktor Yang Dapat Memotivasi Mahasiswa Berkeinginan Wirausaha. Fakultas Ekonomi Jurusan Manajemen, Universitas Gunadarma.

Putu Eka Desy Yanti, I Made Nuridja Dan I Ketut Dunia.2014"Pengaruh Lingkungan Keluarga Terhadap Berwirausaha Siswa Kelas Xi Smk Negeri 1 Singaraja" Jurusan Pendidikan Ekonomi Universitas Pendidikan Ganesha Singaraja, Indonesia

Randy Chirtianto Vincentius. 2013. Pembuatan Sistem Informasi Perusahaan Karaoke. Universitas Surabaya.

Ranto Basuki. 2007. Korelasi antara Motivasi, Knowledge of Entreprenurship dan Indepen-densi dan The Entrepreneur's Performance pada Kawasan Industri Kecil, Manajemen Usahawan Indonesia, LMFE-UI, Jakarta.

Riyanti, Benedicta Prihatin Dwi, 2003. Kewirausahaan Dipandang dari Sudut Pandang Psikologi Kepribadian, Cetakan Pertama, Penerbit PT Grasindo, Jakarta.

Sardiman A.M. 2006. Interaksi dan Motivasi Belajar Mengajar. Jakarta. Raja Grafindo Persada 
Saud Udin Syaefudin. 2010. Pengembangan Profesi Guru. Bandung: Alfabeta

Sedarmayanti.2007.Sumber Daya Manusia dan Produktivitas Kerja. Bandung: Mandar Maju

Sugiyono. 2008. Metode Penelitian Kunatitatif Kualitatif dan $R \& D$. Bandung Alfabeta. , 2009. Metode Penelitian Kuantitatif dan Kualitatif. CV. Alfabeta: Bandung. 2010. Metode Penelitian Kuantitatif Kualitatif dan $R \& D$, Alfabeta Bandung.

Suhartini Yati. 2011. Analisis Faktor-Faktor Yang Mempengaruhi Minat Mahasiswa dalam Berwiraswasta. Jurnal Akmenika UPY, Vol. 7, 2011.

Suryana. 2003. Kewirausahaan Pedoman Praktis, Kiat dan Proses Menuju Sukses. Bandung: Salemba Empat.

Suryana. (2010). Kewirausahaan. Jakarta: Salemba Empat.

Uno, Hamzah. 2008. Teori Motivasi \& Pengukurannya Analisis Dibidang Pendidikan. Jakarta. Bumi Aksara.

Usman dan Akbar. 2009. Metode Penelitian Sosial. Jakarta: Bumi Aksara

Wibisono, Dermawan. 2006. Manajemen Kinerja, Penerbit Erlangga, Jakarta.

Ximenes Ximenes (2014),The Influence of Personal and Environmental Factors on Business Start-Ups: A Case Study in the District of Dili and Oecusse, Timor-Leste. Journal Of School of Business, University of the Thai Chamber of Commerce,

Zimmerer, W.T. 2008. Essentials of Entrepreneurship and Small Business Management. Third Edition. New York: Prentice-Hall 